WARSZTATY Z GEOGRAFII TURYZMU

ISBN 978-83-7525-925-4 $\quad$ s. $229-240$

http://dx.doi.org/10.18778/7525-925-4.16

Przemysław DiAKów

Państwowa Wyższa Szkoła Zawodowa

im. Angelusa Silesiusa w Wałbrzychu

\title{
ROZMIESZCZENIE BAZY AGROTURYSTYCZNEJ NA DOLNYM ŚLĄSKU NA TLE UWARUNKOWAŃ ŚRODOWISKOWYCH
}

\section{Wprowadzenie}

Dynamiczny rozwój turystyki wiejskiej, w tym agroturystyki w Polsce datuje się od okresu transformacji ustrojowej (WOJCIECHOWSKA 2009), mimo iż jej tradycje sięgają nawet XIX w. Należy zwrócić przy tym uwagę, iż na Dolnym Śląsku agroturystyka po roku 1989 rozwijała się praktycznie od podstaw. Wynikało to z polityki państwa po II wojnie światowej, której celem była kolektywizacja rolnictwa, co nie sprzyjało tej formie turystyki. Trzeba też zauważyć brak tradycji jej uprawiania przez napływową ludność rolniczą (inaczej było np. w Małopolsce czy na Podkarpaciu). Sytuacja ta zmieniła się diametralnie na początku lat 90. XX w., kiedy przemiany ekonomiczne doprowadziły do kryzysu w rolnictwie, nie tylko na terenie Dolnego Śląska, ale całego kraju. Malejąca opłacalność produkcji rolnej doprowadziła do jej ograniczenia oraz znacznego zubożenia rolników. Zmniejszenie dochodów $\mathrm{z}$ produkcji rolnej spowodowało, że rolnicy w coraz większym stopniu poszukiwali dochodów $\mathrm{z}$ różnorodnej działalności pozarolniczej, w tym 
agroturystyki. Dostosowywanie się rolnictwa do gospodarki rynkowej, w połączeniu z innymi czynnikami spowodowało dynamiczny rozwojów agroturystyki. Według danych Wojewódzkiego Ośrodka Doradztwa Rolniczego (WODR) w Świdnicy w roku 2011 na terenie Dolnego Śląska prowadziło działalność ponad 800 gospodarstw agroturystycznych, które dysponowały blisko 8 tys. miejsc noclegowych. Na jedno gospodarstwo agroturystyczne przypadały średnio cztery pokoje, dysponujące około 10 miejscami noclegowymi. Rysunek 1 przedstawia dynamikę przyrostu liczby miejsc noclegowych w gospodarstwach agroturystycznych od roku 1992.

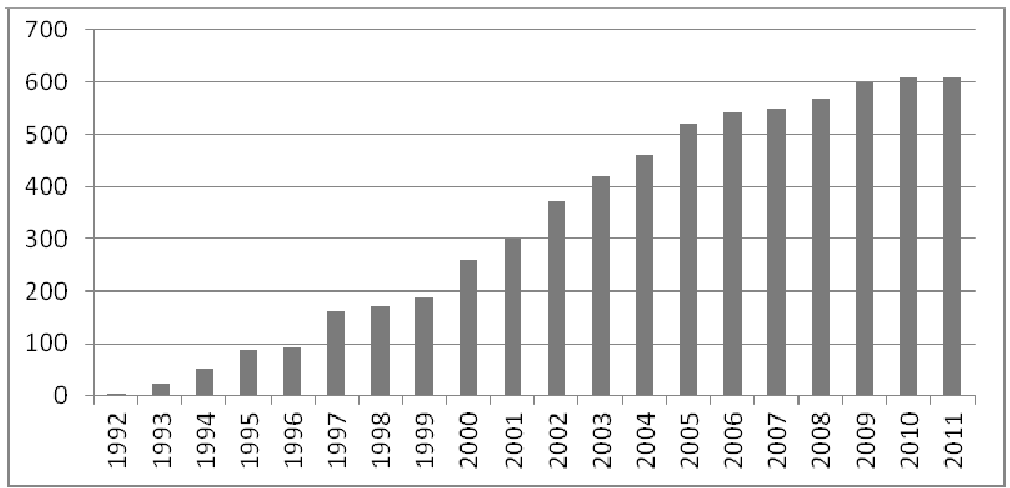

Rys. 1. Rozwój agroturystyki na Dolnym Śląsku w latach 1992-2011 według liczby gospodarstw

Źródło: opracowanie własne na podstawie danych z WODR w Świdnicy

Głównym celem opracowania jest próba analizy powiązań pomiędzy występowaniem walorów wypoczynkowych a rozmieszczeniem gospodarstw agroturystycznych na Dolnym Śląsku, jak również określenie ich lokalizacji na tle waloryzacji rolniczej przestrzeni. Zostanie również przeprowadzona analiza współzależności między warunkami przyrodniczymi a wskaźnikiem walorów wypoczynkowych. Tematyka pracy została zawężona tylko do dwóch rodzajów uwarunkowań, choć należy zaznaczyć, że na rozwój agroturystyki wpływ ma znacznie większa liczba czynników. W celu wykazania wymienionych powiązań zastosowano metodę obliczenia współczynnika korelacji $r$ (Pearsona), a jego istotność testowano testem $t$ - Studenta. 


\section{Współzależność między warunkami przyrodniczymi a wskaźnikiem walorów wypoczynkowych}

Województwo dolnośląskie położone w południowo-zachodniej części Polski jest pod względem warunków środowiska jednym z najbardziej zróżnicowanych regionów w naszym kraju.

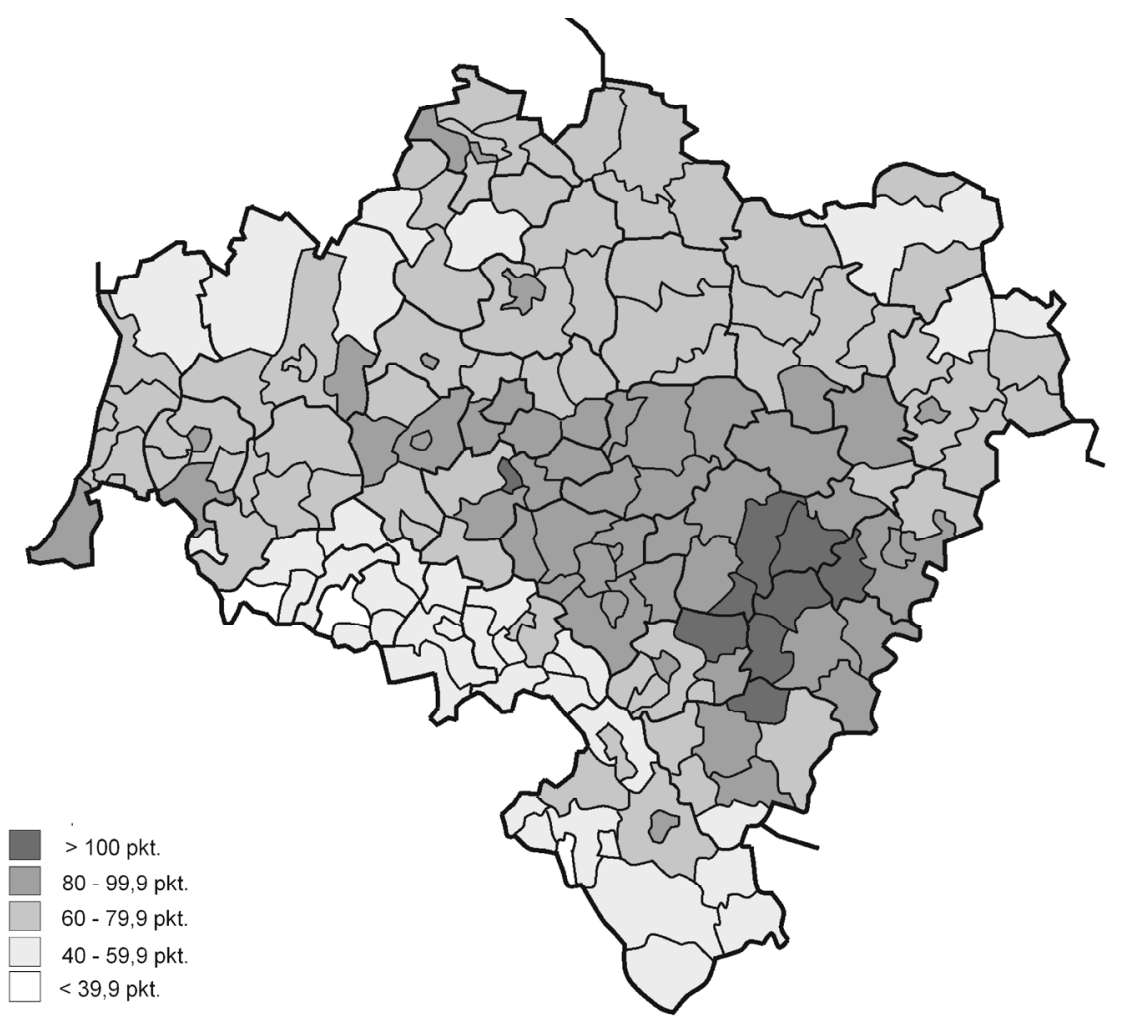

Rys. 2. Wskaźnik jakości rolniczej przestrzeni produkcyjnej w województwie dolnośląskim Źródło: opracowanie własne na podstawie danych z Instytutu Uprawy, Nawożenia i Gleboznawstwa (IUNG) w Puławach

Z analizy rys. 2 wynika, że obszar województwa dolnośląskiego wykazuje duże zróżnicowanie czynników wpływających na wysokość wskaźnika jakości rolniczej przestrzeni produkcyjnej (jrpp). Wyjątkowo korzystne warunki występują w gminach powiatów strzelińskiego, świdnickiego i wroc- 
ławskiego (zdecydowana większość powyżej 90 pkt.), a bardzo korzystne w gminach powiatów dzierżoniowskiego, oławskiego i średzkiego (zdecydowana większość powyżej 80 pkt.). Południową część województwa zajmują obszary charakteryzujące się mało korzystnymi warunkami (gminy w powiatach jeleniogórskim, kłodzkim, wałbrzyskim, a na północy milickim. W przypadku występowania walorów wypoczynkowych (rys. 3) sytuacja przedstawia się zgoła odwrotnie, co potwierdza bardzo silna zależność pomiędzy wskaźnikiem jrpp a występowaniem walorów wypoczynkowych w dolnośląskich gminach.

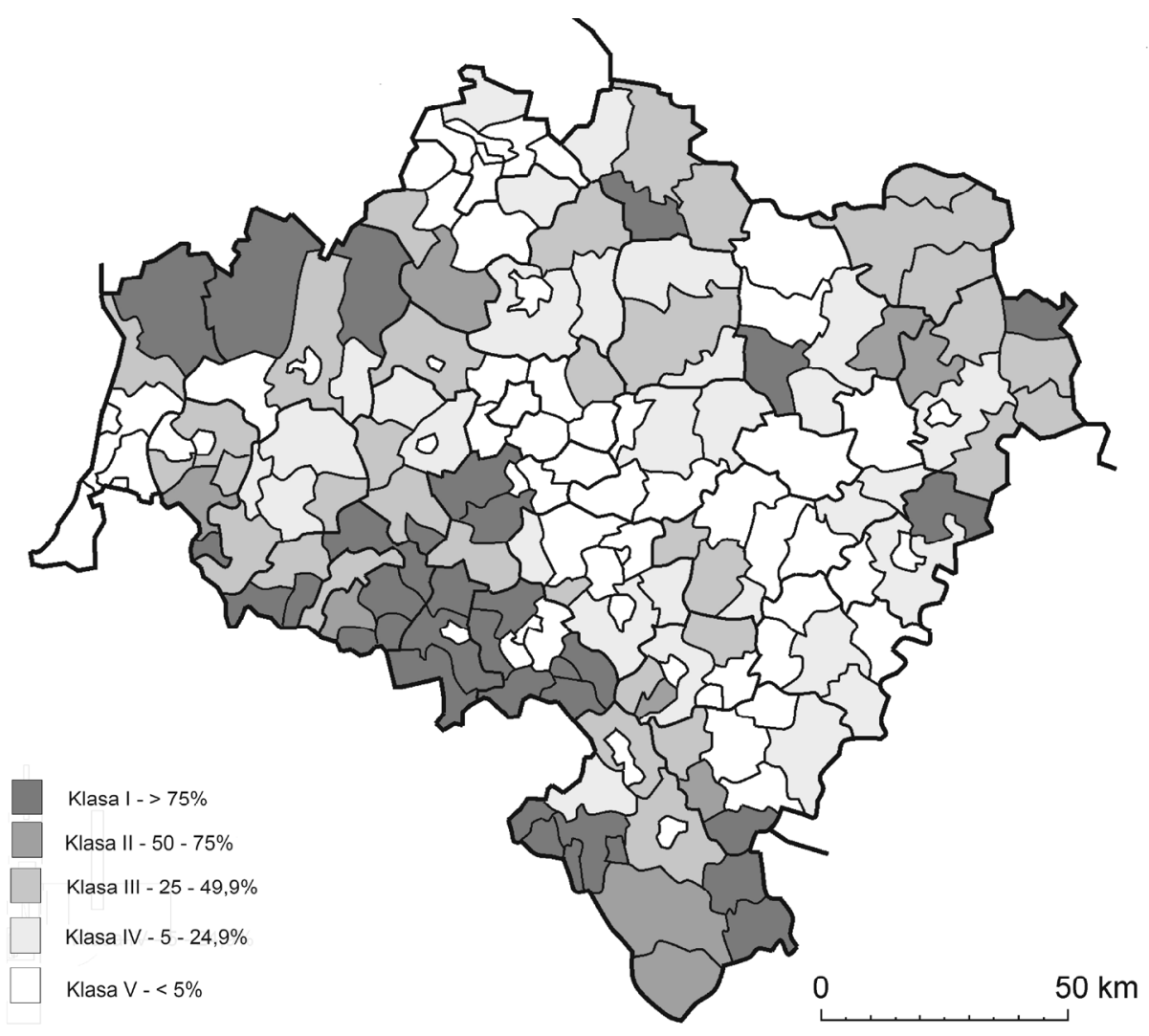

Rys. 3. Wskaźnik walorów wypoczynkowych w województwie dolnośląskim Źródło: opracowanie własne na podstawie danych z Instytutu Turystyki (IT) we Wroclawiu 


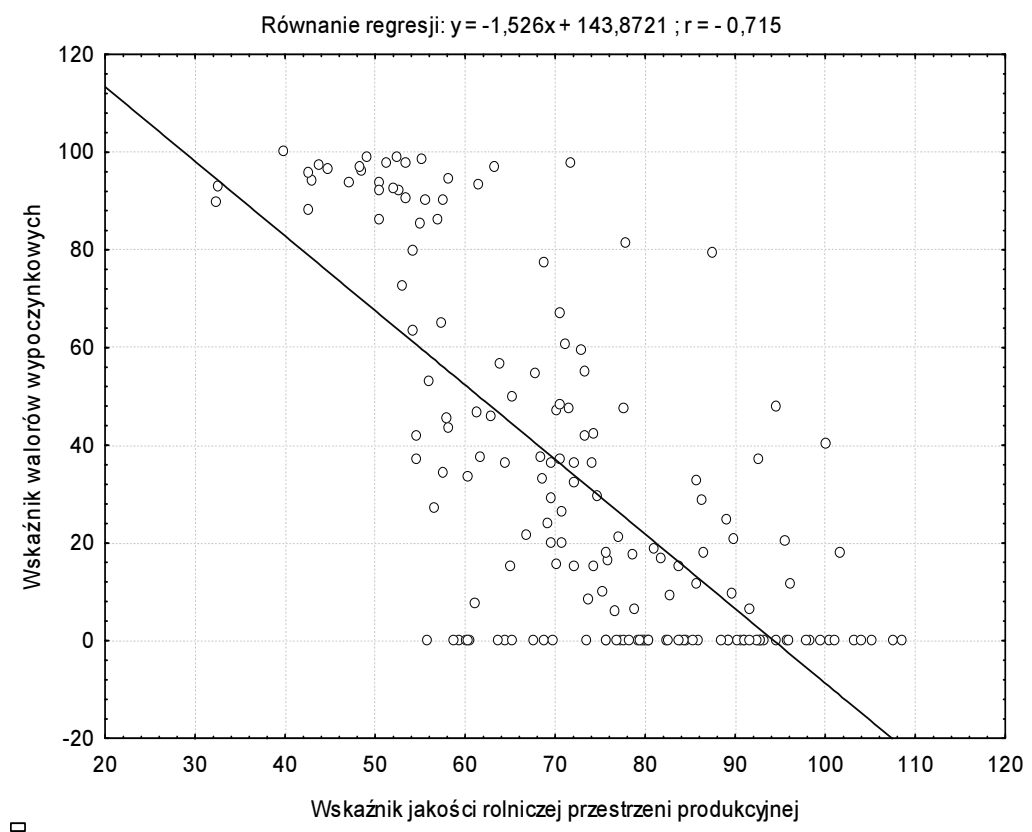

Rys. 4. Współzależność między jakością rolniczej przestrzeni produkcyjnej a walorami wypoczynkowymi w województwie dolnośląskim

Źródło: opracowanie własne na podstawie danych IUNG w Puławach oraz IT we Wrocławiu

Współczynnik korelacji pomiędzy wymienionymi zmiennymi wynosi $r=-0,711$ przy poziomie ufności poniżej 0,001. Wysoka wartości współczynnika korelacji uzasadnia celowość obliczenia równania regresji, które pozwala na oszacowanie wielkości cechy y na podstawie cechy x.

\section{Uwarunkowania i czynniki rozwoju agroturystyki na Dolnym Śląsku}

Na rozwój turystyki wiejskiej, w tym agroturystyki, wpływa wiele różnorodnych uwarunkowań (przyrodniczych, ekonomiczno-społecznych, politycznych i innych). Rozwoju agroturystyki można upatrywać w przesłankach wymienionych poniżej, przy czym należy zaznaczyć, że nie są one uniwersalne i na różnych obszarach mogą oddziaływać w różnym stopniu. Do najważniejszych z nich należą (BALIŃSKA, SIKORSKA-WOLAK 2009): 
- atrakcyjność turystyczna (w tym walory turystyczne);

- siła nabywcza ludności;

- dywersyfikacja oferty wypoczynku w ramach turystyki wiejskiej;

- procesy urbanizacji;

- rozwój infrastruktury komunikacyjnej;

- „moda” na wypoczynek w gospodarstwie rolnym;

- zapotrzebowanie na zdrowy, ekologiczny sposób żywienia i wypoczynku;

- całoroczny sezon - wypoczynek świąteczny i weekendowy, przedłużone weekendy;

- konkurencyjność cen w porównaniu do turystyki masowej;

- zmiany polskiej wsi;

- wzrost aktywności gospodarczej ludności wiejskiej;

- charakter polskiego rolnictwa;

- wzrost świadomości podejmowania działań pozarolniczych, w celu uzyskania dodatkowych źródeł dochodu;

- wolne zasoby mieszkaniowe na wsi;

- pozytywne postrzeganie przez władze samorządowe agroturystyki jako istotnego elementu wielofunkcyjnego rozwoju wsi;

- działalność ośrodków doradztwa rolniczego;

- działalność organizacji społecznych i gospodarczych;

- możliwość pozyskania środków finansowych na rozwój agroturystyki i turystyki wiejskiej;

- miejsce turystyki wiejskiej, w tym agroturystyki w dokumentach strategicznych.

\section{Rozmieszczenie gospodarstw agroturystycznych na tle występowania wskaźnika walorów wypoczynkowych}

Walory wypoczynkowe służą regeneracji sił fizycznych i psychicznych człowieka. T. LIJEWSKI, B. MIKUŁOWSKI, J. WYRZYKOWSKI (2002) wyróżniają w grupie walorów wypoczynkowych zespół cech niezbędnych, których występowanie stanowi minimum warunków do wypoczynku, oraz zespół cech korzystnych, podnoszących wartości wypoczynkowe terenu. Do cech niezbędnych zalicza czyste powietrze, ciszę, spokój, niski stopień urbanizacji, 
występowanie walorów estetycznych krajobrazu, brak zasadniczych przeciwwskazań klimatycznych. Do cech korzystnych: szczególne walory widokowe krajobrazu, warunki do uprawiania czynnego wypoczynku, korzystne warunki bioklimatyczne oraz tzw. walory lecznicze. Dane wykorzystane w opracowaniu pochodzą z bazy danych GMINA opracowanej przez pracowników Instytutu Turystyki (IT) we Wrocławiu. Zaprezentowane w bazie danych walorów wypoczynkowych dla poszczególnych gmin województwa dolnośląskiego pochodzą z opracowania pt. Ocena walorów wypoczynkowych Polski (WERNER 1989). Analizowany wskaźnik walorów wypoczynkowych wyraża udział procentowy powierzchni obszarów z walorami wypoczynkowymi w powierzchni gminy. Według wzoru: powierzchnia obszarów z walorami wypoczynkowymi x 100/ powierzchnię gminy.

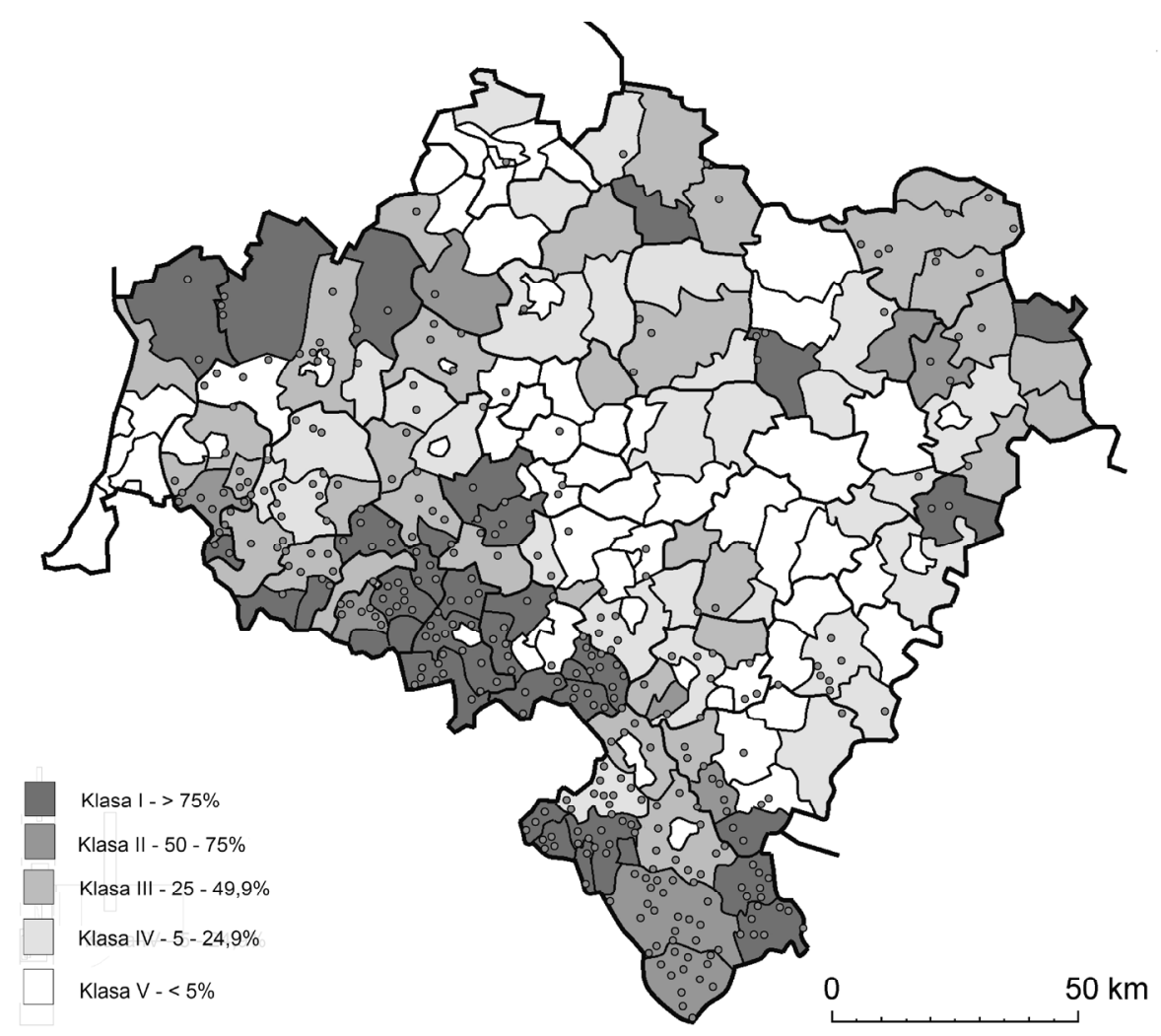

Rys. 5. Rozmieszczenie miejscowości z gospodarstwami agroturystycznymi na tle występowania wskaźnika walorów wypoczynkowych w woj. dolnośląskim Źródło: opracowanie własne na podstawie danych z WODR w Świdnicy oraz IT we Wrocławiu 
Rozmieszczenie miejscowości z gospodarstwami agroturystycznymi na tle występowania wskaźnika walorów wypoczynkowych w województwie dolnośląskim przedstawia rys. 5 .

Wpływ występowania wskaźnika walorów wypoczynkowych na przestrzenne rozmieszczenie gospodarstw agroturystycznych można prześledzić, analizując współczynnik korelacji liniowej między wskaźnikiem występowania walorów wypoczynkowych a liczbą gospodarstw agroturystycznych w poszczególnych gminach województwa dolnośląskiego. Wartość współczynnika korelacji wynosi $r=0,416(p<0,001)$ i jest istotna statystycznie.

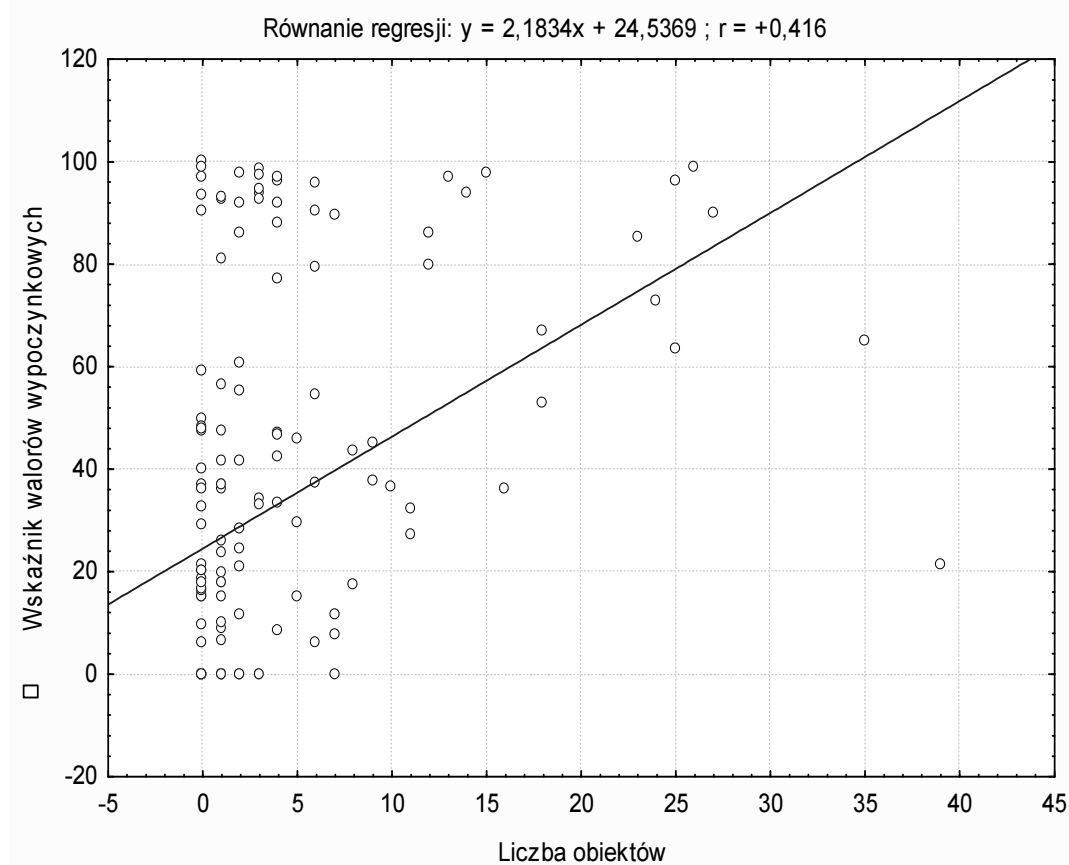

Rys. 6. Współzależność między liczbą gospodarstw agroturystycznych a wskaźnikiem walorów wypoczynkowymi w województwie dolnośląskim Źródło: opracowanie własne na podstawie danych z WODR w Świdnicy oraz IT we Wrocławiu

W gminach charakteryzujących się wysokim wskaźnikiem walorów wypoczynkowych liczba gospodarstw agroturystycznych jest duża. W 44 gmi- 
nach (na 169), mających wskaźnik walorów wypoczynkowych powyżej 50\%, zlokalizowanych jest ponad $60 \%$ wszystkich gospodarstw agroturystycznych województwa, które dysponowały ok. 63\% wszystkich miejsc noclegowych. Przy wskaźniku walorów wypoczynkowych powyżej 75\% w 35 gminach zlokalizowanych jest odpowiednio ok. 39\% gospodarstw z prawie $42 \%$ miejsc noclegowych. Odwrotnie jest w przypadku gmin z małym wskaźnikiem, gdzie liczba gospodarstw jest mała lub nie występują one wcale. Na 92 gminy ze wskaźnikiem walorów wypoczynkowych poniżej 25\% (w tym gminy miejskie) przypada ok. 19\% ogólnej liczby gospodarstw, które dysponowały tylko ponad $18 \%$ miejsc noclegowych. Wypada więc zauważyć, iż rozmieszczenie gospodarstw agroturystycznych jest silnie skorelowane z walorami wypoczynkowymi występującymi w danej gminie.

\section{Rozmieszczenie gospodarstw agroturystycznych na tle wskaźnika waloryzacji rolniczej przestrzeni produkcyjnej}

Kompleksową metodą oceny warunków przyrodniczych pod kątem wpływu na gospodarkę rolną jest opracowana przez Instytut Uprawy, Nawożenia i Gleboznawstwa (IUNG) w Puławach waloryzacja rolniczej przestrzeni produkcyjnej. Jest to syntetyczny miernik, obejmujący cechy jakościowe gleb, rzeźby terenu, agroklimatu i warunków wodnych ze względu na ich przydatność rolniczą. Poszczególne elementy punktowane były proporcjonalnie do ich oddziaływania na produkcję rolniczą: gleby 15-100 pkt., agroklimat 0-15 pkt., rzeźba terenu 0-15 pkt. i stosunki wodne 0-5 pkt. (Waloryzacja... 1981). W punktowej ocenie wymienionych elementów środowiska przyrodniczego największe znaczenie mają warunki glebowe. Średni wskaźnik jrpp dla gmin województwa dolnośląskiego jest wysoki - wynosi ponad 72, bowiem średnia wartość dla Polski to 66,6 pkt. Najlepsze warunki przyrodnicze dla produkcji rolnej ma Nizina Śląska. Rozmieszczenie miejscowości z gospodarstwami agroturystycznymi na tle występowania wskaźnika jakości rolniczej przestrzeni produkcyjnej w województwie dolnośląskim przedstawia rys. 7 . 


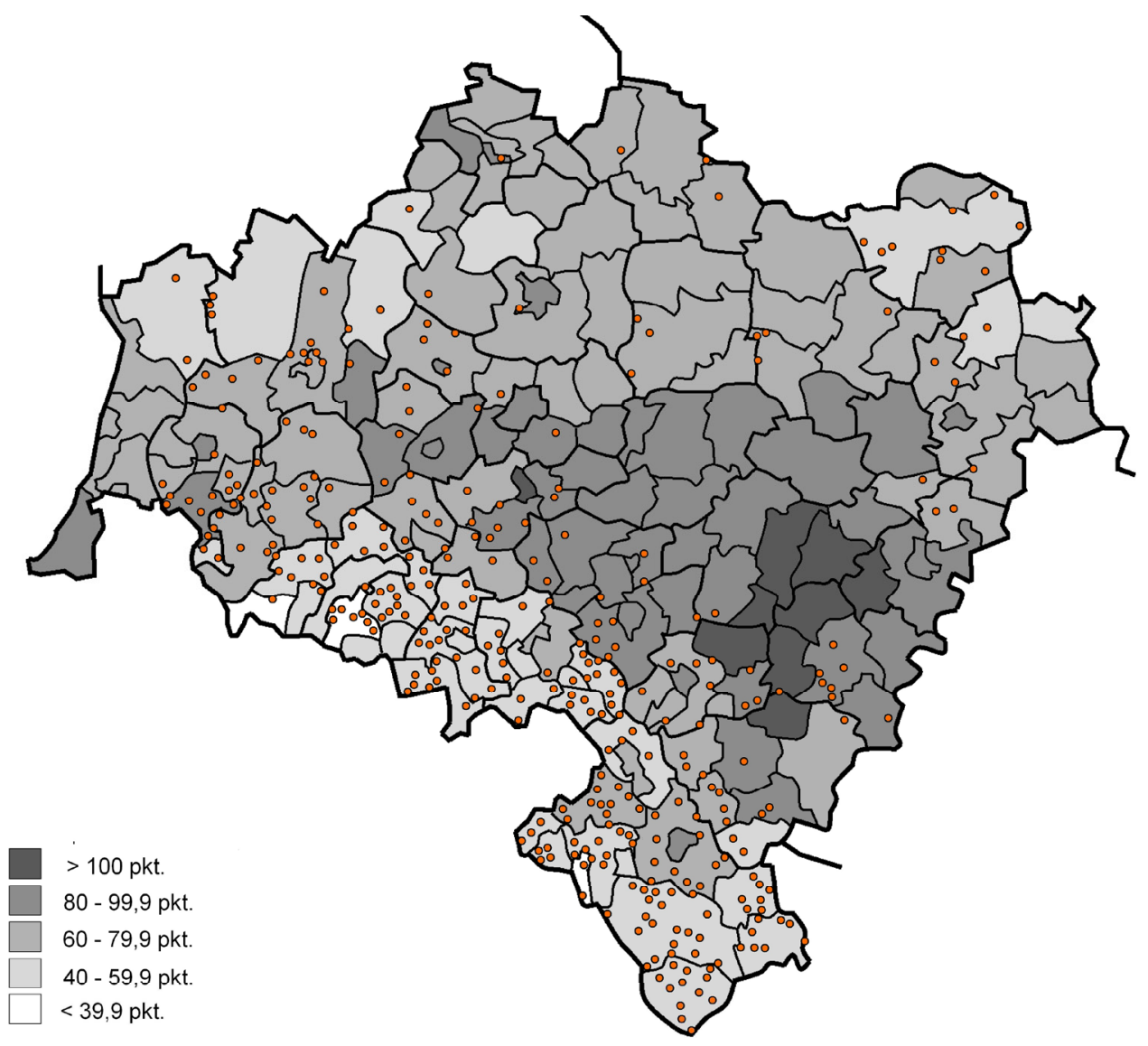

Rys. 7. Rozmieszczenie miejscowości z gospodarstwami agroturystycznymi na tle jakości rolniczej przestrzeni produkcyjnej w województwie dolnośląskim Źródło: opracowanie własne na podstawie danych z WODR w Świdnicy oraz IUNG w Puławach

Wpływ jakości rolniczej przestrzeni produkcyjnej na rozmieszczenie gospodarstw agroturystycznych można prześledzić analizując współczynnik korelacji liniowej między wskaźnikiem jrpp a liczbą gospodarstw agroturystycznych w gminach województwa dolnośląskiego. Wartość wskaźnika korelacji wynosi $r=-0,401(p<0,001)$ i jest istotna statystycznie.

Aż 34\% gmin charakteryzuje się wskaźnikiem wyższym niż $80 \%$, z czego większość położona jest na terenie Niziny Śląskiej. W gminach charakte- 


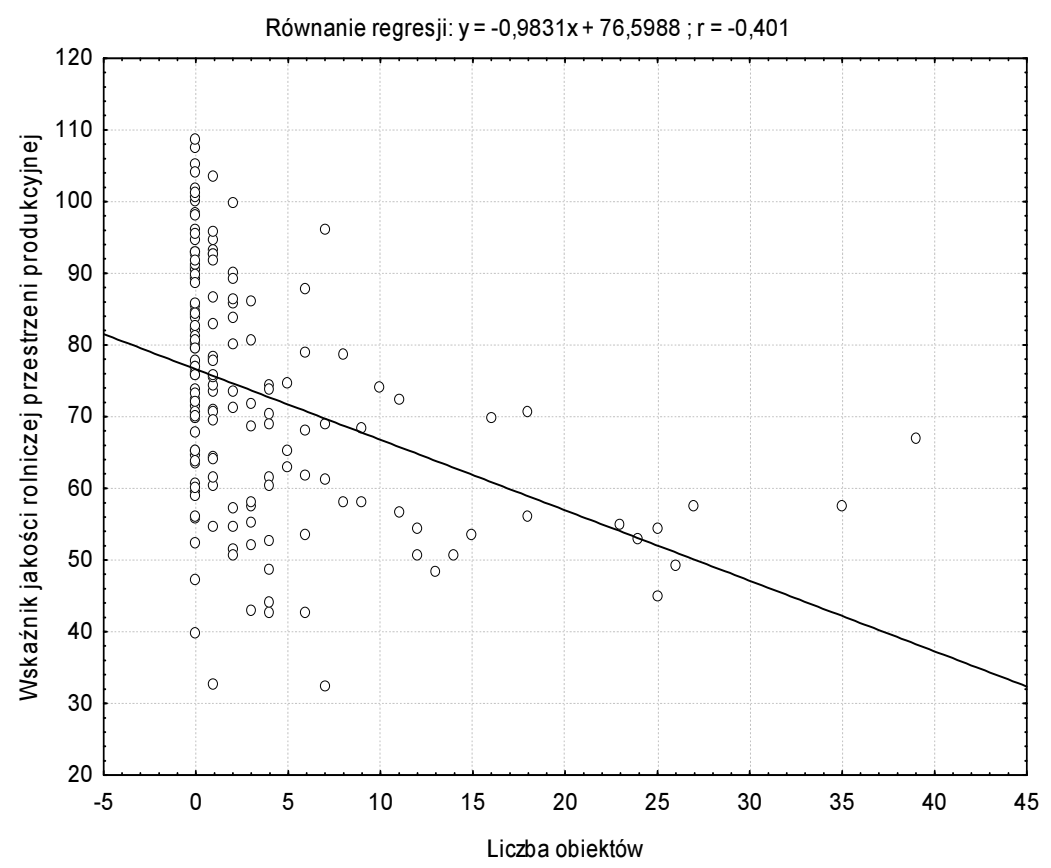

Rys. 8. Współzależność między liczbą gospodarstw agroturystycznych a wskaźnikiem jakości rolniczej przestrzeni produkcyjnej w woj. dolnośląskim Źródło: opracowanie własne na podstawie danych z WODR w Świdnicy oraz IUNG w Puławach

ryzujących się najwyższymi wartościami wskaźnika zlokalizowanych jest około 5\% ogólnej liczby gospodarstw agroturystycznych, zaś w dziewięciu gminach ze wskaźnikiem powyżej 100 tylko jedno. Podsumowując, należy stwierdzić, że w gminach charakteryzujących się wysokim wskaźnikiem jrpp liczba gospodarstw jest mała lub nie występuje wcale. Potwierdza to wniosek, że im lepsze warunki do produkcji rolniczej, tym mniejsza motywacja poszukiwania dodatkowych źródeł dochodu z działalności pozarolniczej. Odwrotna zależność występuje w przypadku gmin z małym wskaźnikiem jrpp (poniżej 60 pkt.), które stanowią 24\% gmin województwa dolnośląskiego, w których zlokalizowanych jest ponad 44\% wszystkich gospodarstw (357 na 808). 


\section{Wnioski}

Przeprowadzona przez autora analiza statystyczna wykazała istnienie współzależności miedzy rozmieszczeniem bazy agroturystycznej na Dolnym Śląsku a wybranymi uwarunkowaniami środowiskowymi. Rozmieszczenie gospodarstw agroturystycznych jest silnie dodatnio skorelowane $\mathrm{z}$ walorami wypoczynkowymi występującymi w gminach województwa dolnośląskiego. Podobnie silna, lecz ujemna korelacja występuje pomiędzy bazą agroturystyczną a wskaźnikiem jakości rolniczej przestrzeni produkcyjnej.

W wyniku tej analizy można stwierdzić, że omawiane uwarunkowania środowiskowe mają istotne znaczenie dla rozmieszczenia i wielkości bazy agroturystycznej $\mathrm{w}$ województwie dolnośląskim. Czynniki przyrodnicze w znacznym stopniu determinują bowiem jej rozmieszczenie. Nie oznacza to jednak, że działalność agroturystyczna nie może rozwinąć się na terenach o mniejszych walorach przyrodniczych, ponieważ niejednokrotnie równie istotne są pozaprzyrodnicze uwarunkowania. Określenie, które z nich i w jakim stopniu wpływają na rozwój agroturystyki, wydaje się być interesującym zagadnieniem przyszłych badań.

\section{BIBLIOGRAFIA}

BALIŃSKA A., SIKORSKA-WOLAK I., 2009, Turystyka wiejska szansq rozwoju wschodnich terenów przygranicznych na przykładzie wybranych gmin, Wyd. SGGW, Warszawa, s. 31-32.

LIJEWSKI T., MiKUŁOWSKI B., WYRZYKOWSKI J., 2002, Geografia turystyki Polski, PWE, Warszawa. Waloryzacja rolniczej przestrzenni produkcyjnej Polski według gmin, 1981, IUNG, Puławy.

WERNER Z. (red.), 1989, Ocena walorów wypoczynkowych Polski, Instytut Turystyki Oddział we Wrocławiu (mps).

WOJCIECHOWSKA J., 2009, Procesy i uwarunkowania rozwoju agroturystyki w Polsce, Wyd. Uniwersytetu Łódzkiego, s. 15-17.

http:// www.dodr.pl.

http:// www.intur.com.pl. 